\title{
Spectral Analysis of Azo Derivatives for their Colorimetric Response to some Special Metal Ions
}

\author{
Kanchan Damade 1,*iD \\ 1 Department of Chemistry; Arts, Commerce and Science College, Bodwad, (India); Kanchan_Damade@rediffmail.com \\ (K.D.); \\ * Correspondence: Kanchan_damade@ @rediffmail.com (K.D.);
}

Received: 8.04.2021; Revised: 5.07.2021; Accepted: 8.07.2021; Published: 12.09.2021

\begin{abstract}
The present study describes an efficient chromogenic probing ability possessed by an azo linkage that could sense $\mathrm{Ni}, \mathrm{Fe}$, and $\mathrm{Co}$ in the semi-aqueous medium. The chromogenic sensing properties of the four azo dyes were studied towards $\mathrm{Fe}(\mathrm{III}), \mathrm{Co}(\mathrm{II})$, and $\mathrm{Ni}(\mathrm{II})$ ions, the IR and UVVIS spectral data revealed that the nitrogen and oxygen atoms of $-\mathrm{N}=\mathrm{N}-, \mathrm{C}=\mathrm{O}$ and $-\mathrm{OH}$ groups participated in bonding with the metal ions. Also, an obvious change in the color of the azo dyes A and B solution from yellow to dark brown in the case of $\mathrm{Fe}^{+2}$ metal ions and $\mathrm{Co}^{+2}$ and $\mathrm{Ni}^{+2}$ colorless solutions appeared yellowish, while the addition of other metal ions did not cause any color change. These results imply that the two azo dyes are viable, portable chromogenic chemosensors for the detection of Fe (III), Co (II), and Ni (II) ions in various biological and environmental fields.
\end{abstract}

Keywords: azo compounds; chromogenic; chemosensor; naked eye; colorimetric response, U.V. bands; characterization; spectral analysis.

(c) 2021 by the authors. This article is an open-access article distributed under the terms and conditions of the Creative Commons Attribution (CC BY) license (https://creativecommons.org/licenses/by/4.0/).

\section{Introduction}

Azo dyes have usually been used as colorimetric sensors for their strong chromogenic behavior against analytes like metal cations or anions. [1, 2]. The remarkable receptor-ion interaction can cause the absorption band of azo dye to shift to a visible light region in the presence of a certain ion which makes azo compounds an efficient chromogenic sensor against various charged analytes and amino acids [3, 4]. Recently, we have reported sensing properties of azo-dye based on 2-hydroxy naphthaldehyde, 2-ter-butyl 4-methoxy phenol unit for colorimetric sensing of various cations; these are chelate dyes having complexing group adjacent to the chromophoric portion which binds metal strongly and imparts color change to the metal salts solution. Rawther \& Nair also proposed from the FT-IR information that the $\mathrm{OH}$ group involves coordination along with azo linkage $(\mathrm{N}=\mathrm{N})$ and the carbonyl group of the aromatic ring [5, 6]. Designing this substituted aniline derivative into azo-dye enhanced its chromogenic ability and enabled metal ion sensing in the semi-aqueous medium. This paper describes an efficient chromogenic probe possessing an azo linkage that could sense Nickle, Iron, and Cobalt in a semi-aqueous medium (ETOH: $\mathrm{H}_{2} \mathrm{O}$; v/v 8:2) at $\mathrm{pH}$ 7.0. As the optical changes occurred within the range of the visible region, so naked-eye color changes are observed, making probe-A and B efficient sensors against the Nickel, Ferrous, and Cobalt metal ions. 


\section{Materials and Methods}

All reagents used for synthesis were obtained commercially and used without further purification. 2-hydroxy naphthaldehyde, 2-ter-butyl 4-methoxy phenol, and substituted aniline were the starting materials used. In the sensing analysis, all the metal cations were added in the form of their respective salts; likewise, iron, nickel, magnesium, mercury as their chlorides, and Zinc, cobalt, copper, lead were added as sulfates, manganese, and sodium were added as their acetates. Analytical grade solvents such as ethanol (EtOH) and $\mathrm{HCl}$ were purchased from Sigma Aldrich and used. Shimadzu UV-2600 UV-vis spectrophotometer was used to record UV-vis spectra. The IR spectra of the chemosensor were recorded on a Perkin Elmer FT-IR spectrometer in the range $4000-400 \mathrm{~cm}^{-1}, 0.1 \mathrm{M}$ solution of all compounds in mixed ethanol and $0.1 \mathrm{M}$ solutions of all cations in $\mathrm{H}_{2} \mathrm{O}$ were prepared.

\subsection{Synthesis of azo ligands.}

The synthesis of azo compounds A-D is depicted in Scheme 1 and 2. The diazocoupling [7] reaction of substituted aniline with 2-hydroxy naphthaldehyde, 2-ter-butyl 4methoxy phenol results in the formation of Azo compounds A, B, C, and D.<smiles>[R]c1ccc(N)nc1</smiles><smiles>Nc1ccc(I)cn1</smiles>

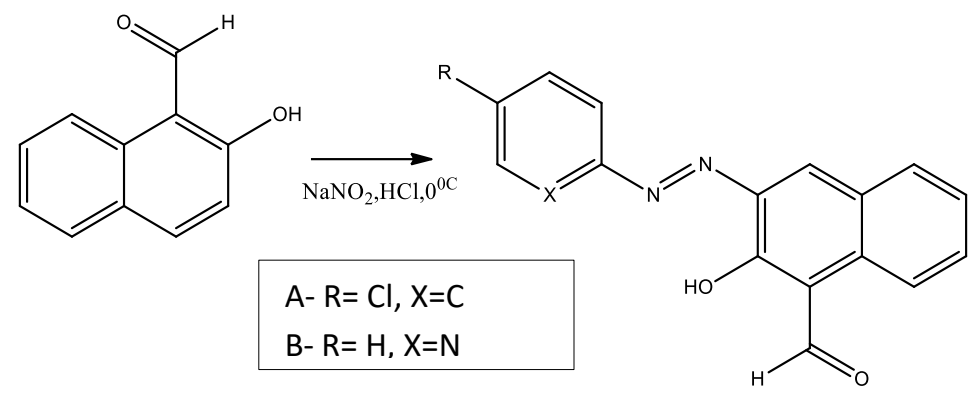

Scheme 1. Synthesis of Azo compounds A and B.



Scheme 2. Synthesis of Azo compounds C and D.

In our present experiments, azo solutions were gradually added to the solution of metal salts in aqueous ethanol. The Probing abilities of compounds A-D with metal ions were investigated by the UV-vis absorption technique and IR data.

2.1.1. Strutcural view of azo derivatives.<smiles>O=Cc1c(O)ccc2cccc(/N=N/c3ccc(Cl)cc3)c12</smiles>

A<smiles>O=Cc1c(O)ccc2cccc(/N=N\c3ccccn3)c12</smiles>

B
(E)-6-((4-chlorophenyl)diazenyl)-2-hydroxy-1naphthaldehyde
(E)-2-hydroxy-6-(pyridin-2-yldiazenyl)-1naphthaldehyde 


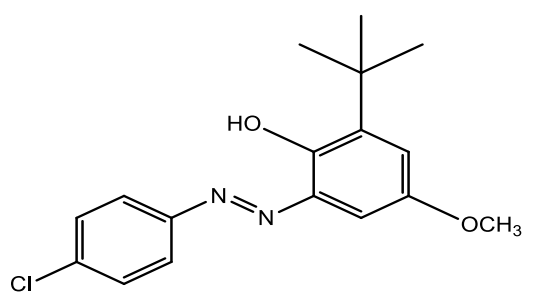

C

(E)-2-(tert-butyl)-6-((4-chlorophenyl)diazenyl)4-methoxyphenol

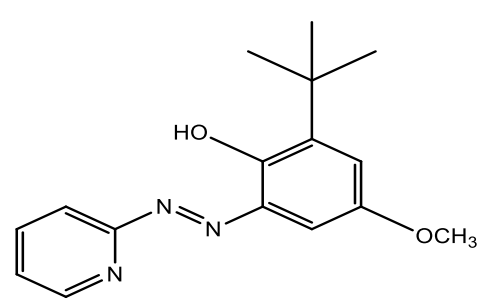

D

(E)-2-(tert-butyl)-4-methoxy-6-(pyridin-2yldiazenyl)phenol

Scheme 3. Molecular Structures of the azo-based probing unit.

\section{Results and Discussion}

\subsection{Metal ion sensing.}

With an objective to evaluate the potential application of probe A - D as a chromogenic sensor, we have investigated its probing efficiency with various metal ions using UV-vis and IR spectroscopy. The recognition and sensing ability of $\mathrm{A}$ and $\mathrm{B}$ which is nearly similar towards various cations, i.e. $\mathrm{Na}^{+}, \mathrm{Pb}^{+2}, \mathrm{Mg}^{+2}, \mathrm{Ag}^{+3}, \mathrm{NH}_{4}^{+2}, \mathrm{Mn}^{+2}, \mathrm{Zn}^{+2}, \mathrm{Ni}^{+2}, \mathrm{Fe}^{+2}, \mathrm{Co}^{+2}, \mathrm{Sn}^{+2}$ are investigated by Infra-Red and UV-vis absorption spectroscopy in 8: 2(v/v) aqueous ethanol ( $\mathrm{pH}$ 7.0). Upon addition of metal ions to the solution of A-D in the same solvent conditions, precipitation occurred. So, binding studies of $\mathrm{Fe}^{+2}, \mathrm{Ni}^{+2}$, and $\mathrm{Co}^{+2}$ ions could not be evaluated. [8].

\subsection{Colorimetric analysis.}

The 8:2 (v/v) ethanolic solution of chemosensor A and B (0.1 M) (pH 7.0) appears dark reddish colour. Among the competitive metal ions such as $\mathrm{Na}^{+}, \mathrm{Pb}^{+2}, \mathrm{Mg}^{+2}, \mathrm{Ag}^{+3}, \mathrm{NH}_{4}^{+2}, \mathrm{Mn}^{+2}$, $\mathrm{Zn}^{+2}, \mathrm{Ni}^{+2}, \mathrm{Fe}^{+2}, \mathrm{Co}^{+2}, \mathrm{Sn}^{+2}$ tested, a conspicuous color change from yellow to dark brown in the case of $\mathrm{Fe}^{+2}$ metal ions was observed while $\mathrm{Co}^{+2}$ and $\mathrm{Ni}^{+2}$ solutions appeared yellowish when probes $\mathrm{A}$ and $\mathrm{B}$ is added (Fig. 2 and 3). At the same time, Compound $\mathrm{C}$ and $\mathrm{D}$ show small colorimetric changes only in $\mathrm{Fe}^{+2}$ solution (Fig. 1).

\subsection{Visual sensor study.}

Multiple responsive azo-linked polycyclic aromatic hydrocarbons (A-D) were synthesized and well-characterized using UV-VIS and IR spectroscopic analysis. The two receptors out of four exhibit multiple responses toward $\mathrm{Ni}^{+2}, \mathrm{Fe}^{+3}$ and $\mathrm{Co}^{+2}$ ions. In the nakedeye analysis, the presence of 2 equiv. of $\mathrm{A}$ and $\mathrm{B}$ in metal ions, $\mathrm{Fe}^{+3}, \mathrm{Ni}^{+2}$, and $\mathrm{Co}^{+2}$ ions make sudden color turn-on changes (yellow to dark brown and colorless to yellow, respectively), whereas Compound $\mathrm{C}$ also shown color changes with $\mathrm{Fe}^{+3}$ (yellow to yellowish-orange). The other competing ions, $\mathrm{Na}^{+}, \mathrm{Pb}^{+2}, \mathrm{Mg}^{+2}, \mathrm{Ag}^{+3}, \mathrm{NH}_{4}{ }^{+2}, \mathrm{Mn}^{+2}, \mathrm{Zn}^{+2}, \mathrm{Sn}^{+2}$, were found insensible toward all four. The color changes indicate the formation of metal complexes with $\mathrm{A}$ and $\mathrm{B}$ and $\mathrm{C} / \mathrm{Fe}^{+3}$ [9]. Although, $\mathrm{Ni}^{+2}$ and $\mathrm{Co}^{+2}$ induced small redshifts in the absorption spectra of probes $\mathrm{A}$ and $\mathrm{B}$, they can be an effective probing unit for these metals. However minimal and similar color change (colorless to yellow) in the presence of $\mathrm{Ni}^{+2}$ and $\mathrm{Co}^{+2}$, the $\mathrm{A}$ and $\mathrm{B}$ cannot be used for selective naked-eye detection for both of these ions in combination. The visual results for the $\mathrm{C}$ and $\mathrm{D}$ metal complex are not clear; therefore, IR analysis is not discussed in the present study. 


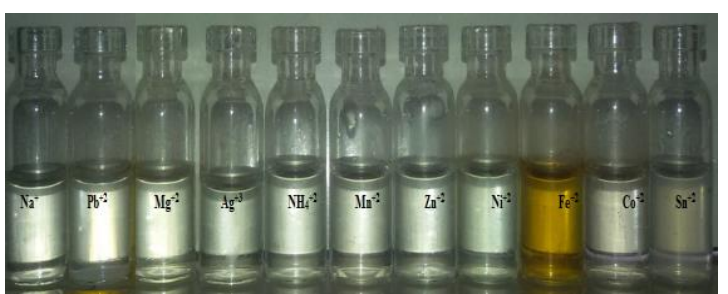

(a)



(c)



(b)

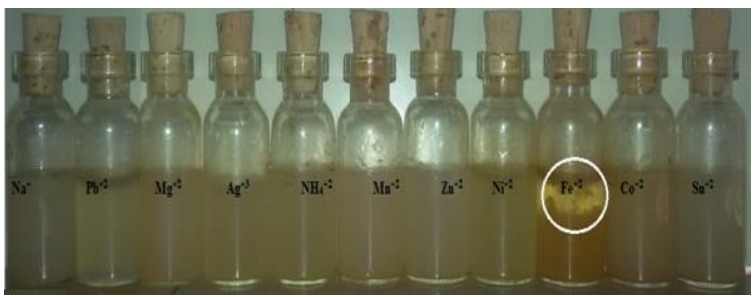

(d)



(e)

Figure 1. Photographic view of chromogenic changes of probes A-D (a) Metal salts solution before addition of probing units. (b) Visual changes in salt solutions after addition of probe A. (c) Visual changes in salt solutions after addition of probe B . (d) Visual changes in salt solutions after addition of probe C. (e) Visual changes in salt solutions after addition of probe D.

\subsection{Spectrometric studies.}

\subsubsection{UV-Vis absorption spectral studies.}

To further investigate the sensing properties of A-D, UV-vis titration for the complexation of A-D with, $\mathrm{Ni}^{+2}, \mathrm{Fe}^{+2}$, and $\mathrm{Co}^{+2}$ were performed (Fig. 2a) shows the absorption spectra of $\mathrm{A}$ upon sequential addition in metal ions solutions such as $\mathrm{Na}^{+}, \mathrm{Pb}^{+2}, \mathrm{Mg}^{+2}, \mathrm{Ag}^{+3}$, $\mathrm{NH}_{4}^{+2}, \mathrm{Mn}^{+2}, \mathrm{Zn}^{+2}, \mathrm{Ni}^{+2}, \mathrm{Fe}^{+3}, \mathrm{Co}^{+2}, \mathrm{Sn}^{+2}$. A exhibited a clear increase in absorption intensity at $316 \mathrm{~nm}$ and $358 \mathrm{~nm}$ with a significant bathochromic shift of $15-25 \mathrm{~nm}$ and a distinct color change from yellow to dark brown, while for nickel and cobalt ions, it showed colorless to light yellow The redshift indicated that metal ions $\left(\mathrm{Ni}^{+2}, \mathrm{Fe}^{+2}\right.$, and $\left.\mathrm{Co}^{+2}\right)$ are complexed with the non-bonding electron pair of the oxygen atom of a hydroxyl group. Also, a small redshift in the absorption peak position is due to the complexation of metal ions with azo groups $[10,11]$. The chemosensor A and metal ions coordination could enhance pi-delocalization, which is expected to reduce the energy of the $\mathrm{p}-\mathrm{p}^{*}$ transition and therefore accounts for the appearance of a new absorption band at a longer wavelength $(358 \mathrm{~nm})$, resulting in the color change to dark brown color [12] and allowing for visual naked-eye detection [13].

Although $\mathrm{Fe}^{+2}$ ions induced smaller shifts in the absorption spectra of probe-B (Fig. 2b), The UV-vis spectrum of B exhibits the typical UV band at $\lambda \max 316 \mathrm{~nm}$ and a low energy band centered at $\lambda \max 357 \mathrm{~nm}$, which is attributed to the $n \rightarrow \pi^{*}$. The UV-vis study of B (Figure. 2) in the presence of the same metal ions under similar conditions $\mathrm{Ni}^{+2}, \mathrm{Fe}^{+2}$, and $\mathrm{Co}^{+2}$, ions showed a hyperchromic shift (i.e., $316 \mathrm{~nm}$ to $357 \mathrm{~nm}$ for $\mathrm{Ni}^{+2}, \mathrm{Fe}^{+2,}$ and $\mathrm{Co}^{+2}$ ). In the case of compound $\mathrm{C}$, there were no visual or spectrochemical changes were observed (Fig. 3a-c), while gradual addition of $\mathrm{D}$ in $\mathrm{Fe}^{+2}$ ions generates a lower response in absorption band at $227 \mathrm{~nm}$ to 
$230 \mathrm{~nm}$ with an increased absorption intensity at 291nm (Fig. 3d). UV absorbance for Compounds A and B has validated the chromogenic sensing abilities; therefore A and B can be used as an alternative method for detecting $\mathrm{Ni}^{+2}, \mathrm{Fe}^{+3}$, and $\mathrm{Co}^{+2}$ ions in chemical and clinical applications.

\subsubsection{FTIR Spectral studies.}

The main vibrational bands of the FTIR spectrum are assigned to the functional groups of the Azo dyes A and B. In the IR spectra of the complexes, the band in the region 1700$1623 \mathrm{~cm}^{-1}$ gives a clear indication of the chelated $\mathrm{C}=\mathrm{O}$ group suggesting the involvement of carbonyl oxygen of the naphthalene ring in the coordination with metal ions [14]. The strong absorptions at $1450-1510 \mathrm{~cm}^{-1}$ and $1730-1655 \mathrm{~cm}^{-1}$ are typical for $-\mathrm{N}=\mathrm{N}-$ and $\mathrm{C}=\mathrm{O}$ moieties, respectively [15]. The spectrum of the A shows strong bands at 1520- 1461, 3060, and 1243 $\mathrm{cm}-1$ that are assigned to the $v(\mathrm{~N}=\mathrm{N})$ and $v(\mathrm{O}-\mathrm{H})$ phenolic and $v(\mathrm{C}-\mathrm{OH})$ respectively $[16,17]$ (Table 1).

For complexing $\mathrm{A} / \mathrm{Fe}^{+2}$, the band for carbonyl $\left(1623 \mathrm{~cm}^{-1}\right)$ and intramolecular hydrogenbonded -OH group $\left(3060 \mathrm{~cm}^{-1}\right)$ is disappeared, which confirms that Fe metal is coordinated with A through an oxygen atom of $\mathrm{C}=\mathrm{O}$ and $-\mathrm{OH}$ group (Figure 4a), while in case of $\mathrm{B} / \mathrm{Fe}^{+2}$ complex, the IR data shows a decrease in IR $v(\mathrm{~N}=\mathrm{N})$ from 1461 to $1422 \mathrm{~cm}^{-1}$ along with the appearance of a new band at $3200-3250 \mathrm{~cm}$ for $-\mathrm{OH}$ group which confirms coordination of $\mathrm{B}$ with Fe through $\mathrm{N}$ atom of $\mathrm{N}=\mathrm{N}$ and $\mathrm{O}$ atom of $\mathrm{C}=\mathrm{O}$ group [18] (Fig. 4a).

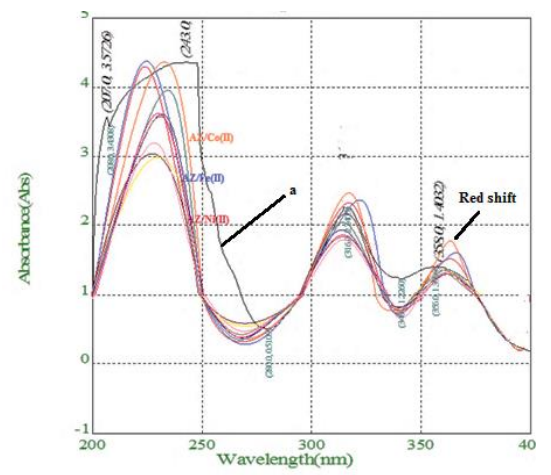

(a)

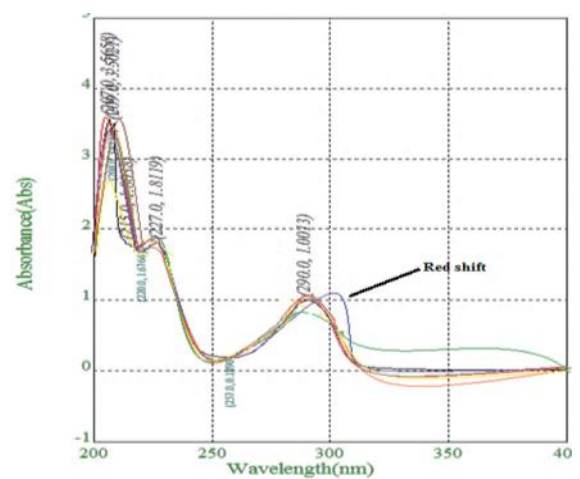

(b)

Figure 2. UV Spectra (a) UV absorbance peaks of Compound-A with respective $\mathrm{M}^{+2}$ solutions; (b) UV absorbance peaks of Compound-B with respective $\mathrm{M}^{+2}$ solution.

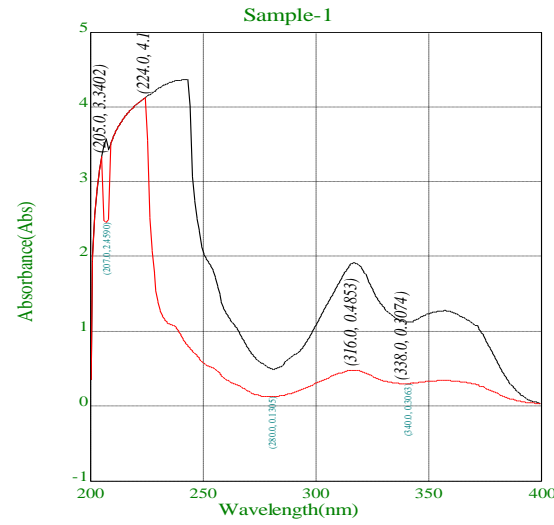

(a)

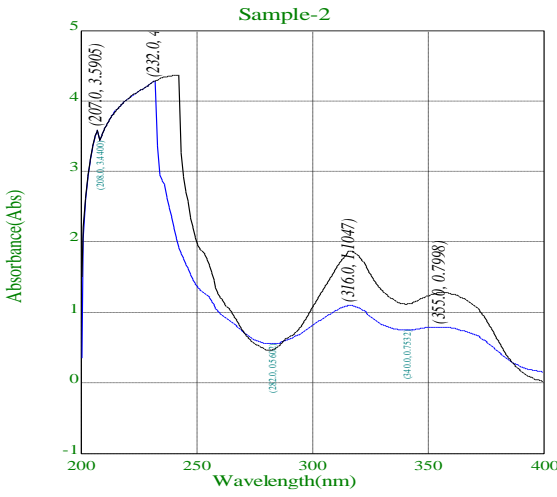

(b) 


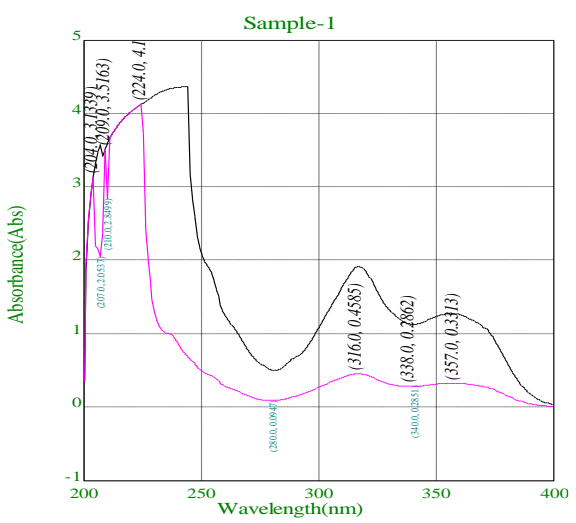

(c)

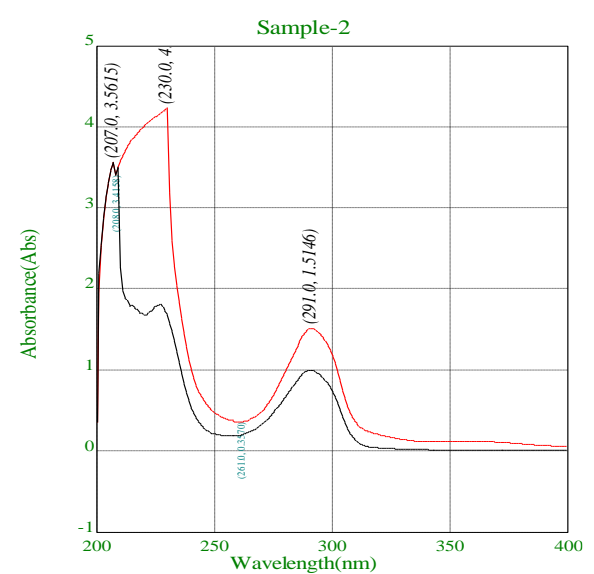

(d)

Figure 3. UV Spectra (a) UV spectra for $\mathrm{C}+\mathrm{Ni}^{+2}$ (b) $\mathrm{UV}$ spectra for $\mathrm{C}+\mathrm{Fe}^{+2}$ (c) $\mathrm{UV}$ spectra for $\mathrm{C}+\mathrm{Co}^{+2}$ $\mathrm{UV}$ absorbance for $\mathrm{D}+\mathrm{Fe}^{+2}$.

In $\mathrm{A} / \mathrm{Ni}^{+2}$ and $\mathrm{B} / \mathrm{Ni}^{+2}$ coordination, [As per Table-1] there was no change in the frequency for chelated carbonyl band at $1623 \mathrm{~cm}^{-1}$ but an increase in $\mathrm{N}=\mathrm{N}$ band frequency up to $1461 \mathrm{~cm}^{-1}$ for both of the complexes; in contrast, the intramolecular hydrogen bonding is as it is for $\mathrm{A} / \mathrm{Ni}^{+2}$ while for $\mathrm{B} / \mathrm{Ni}^{+2}$ it is disappeared with the appearance of the band at $3311 \mathrm{~cm}^{-1}$ which conclude that $\mathrm{A}$ does not form a bond with $\mathrm{Ni}$ ion through $-\mathrm{OH}$ and $\mathrm{C}=\mathrm{O}$ group, while for $\mathrm{B} \mathrm{Ni}$ ion formed a bond through $\mathrm{N}=\mathrm{N}$ and $-\mathrm{OH}$ group (Fig. 4b).

In the case of $\mathrm{A} / \mathrm{Co}^{+2}$ and $\mathrm{B} / \mathrm{Co}^{+2}$ complex, the bands of $v(\mathrm{~N}=\mathrm{N})$ are shifted to lower frequencies from 1461 to $1388 \mathrm{~cm}^{-1}$ and $1422 \mathrm{~cm}^{-1}$ respectively; also the disappearance of IR band for intramolecular $-\mathrm{OH}$ bonding, these shifts confirm the involvement of all three hetero atoms of $\mathrm{N}=\mathrm{N},-\mathrm{OH}$ and $\mathrm{C}=\mathrm{O}$ groups in the coordination of $\mathrm{Co}^{+2}$ with $\mathrm{A}$ and $\mathrm{B}$ (Fig. $4 \mathrm{c}$ ).

Table 1. IR frequencies for $\mathrm{A} / \mathrm{Ni}^{+2}$ and $\mathrm{B} / \mathrm{Ni}^{+2}$ coordination.

\begin{tabular}{|c|c|c|c|c|c|c|}
\hline $\begin{array}{l}\text { Molecular } \\
\text { symbols }\end{array}$ & v $\mathbf{C}=\mathbf{O}$ & v $\mathbf{N}=\mathbf{N}$ & $\mathrm{v}-\mathrm{OH}$ & v-C-H & $v-C=C$ & v C-O \\
\hline A & 1623 & $1450-1520$ & $\begin{array}{l}3060 \\
\text { (intramolecular) }\end{array}$ & $2803-2886$ & $1600-1620$ & 1243 \\
\hline $\mathrm{A} / \mathrm{Fe}^{+2}$ & --- & 1461 & 3339 & 2886 & 1578 & 1159 \\
\hline $\mathrm{A} / \mathbf{N i}^{+2}$ & 1623 & 1461 & 3054 & 2886 & 1590 & 1159 \\
\hline $\mathrm{A} / \mathrm{CO}^{+2}$ & 1623 & 1388-1455 & 3289 & $2800-2900$ & 1570-1590 & 1181 \\
\hline B & 1623 & 1461 & 3060 & 2886 & $1560-1600$ & 1159 \\
\hline $\mathrm{B} / \mathrm{Fe}^{+2}$ & 1620 & 1422 & $3200-3250$ & 2890 & 1530 & 1187 \\
\hline $\mathrm{B} / \mathrm{Ni}^{+2}$ & 1623 & 1461 & 3311 & 2892 & 1600 & 1176 \\
\hline $\mathrm{B} / \mathrm{CO}^{+2}$ & 1634 & 1422 & $3200-3400$ & $2800-2850$ & 1539 & 1181 \\
\hline
\end{tabular}

${ }^{1}$ Table: IR frequencies of various functional groups on coordination of $\mathrm{A} / \mathrm{M}^{+2}$ and $\mathrm{B} / \mathrm{M}^{+2}$

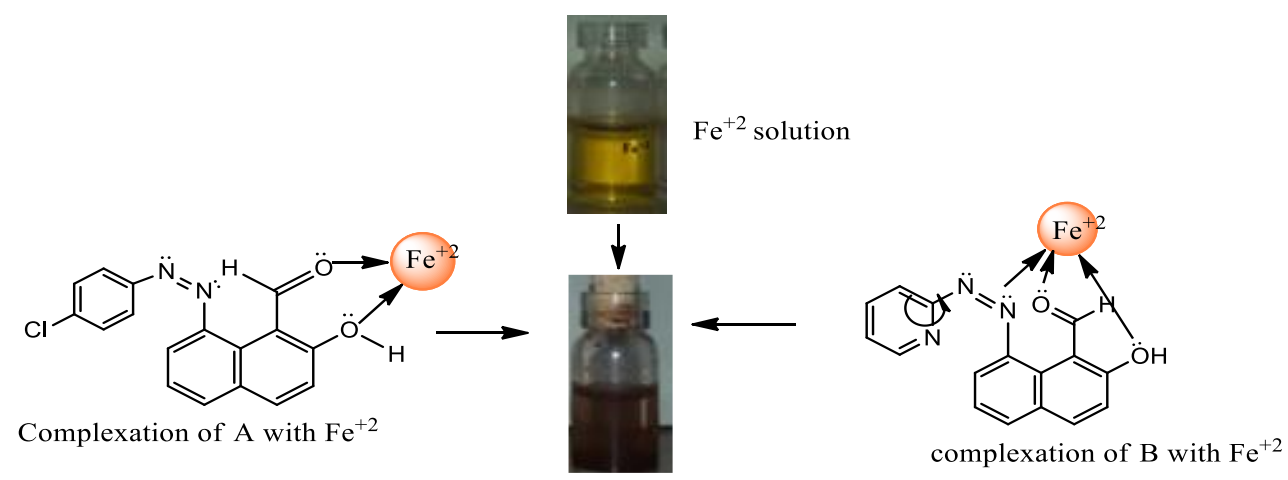

$\mathrm{Fe}^{+2}$ solution when complexed with Azo dye A or B

(a) 


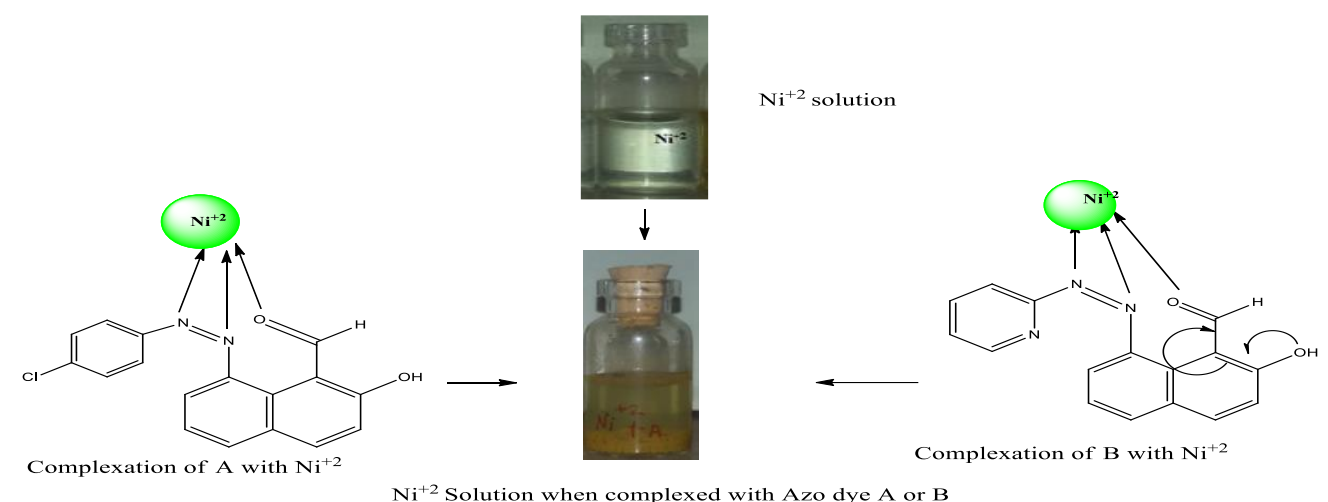

(b)

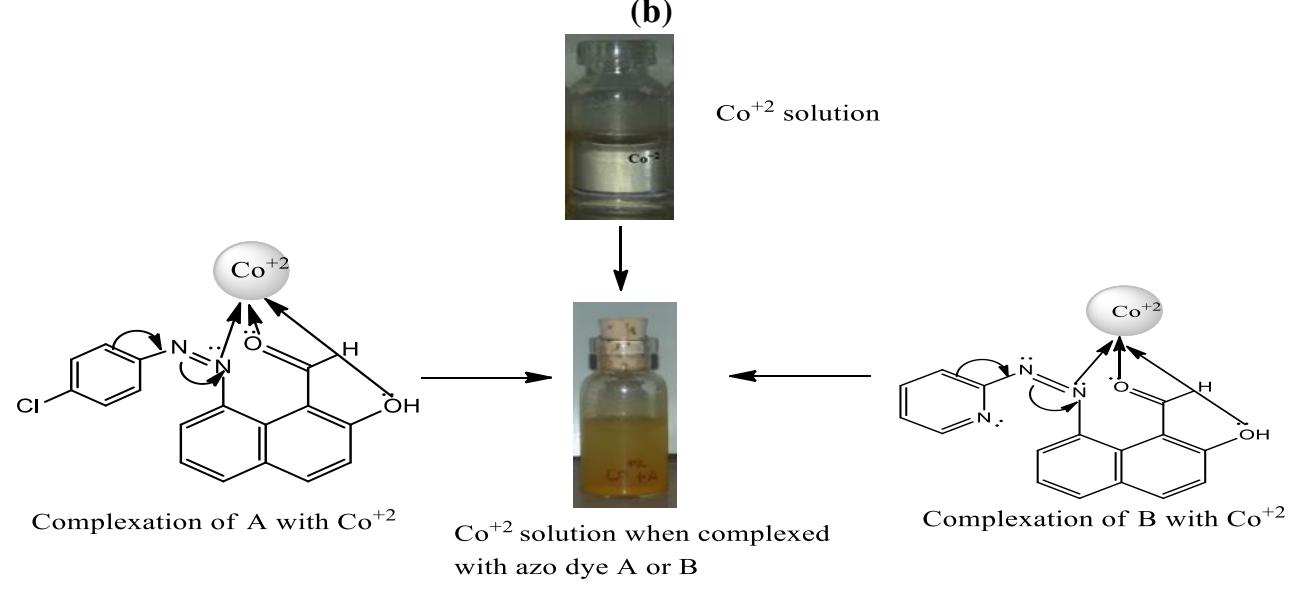

(c)

Figure 4. (a) Structural view of $\mathrm{Fe}^{+2}$ Sensing by Azo dye A and B; (b) Structural view of Sensing of $\mathrm{Ni}^{+2}$ by Azo dye A and B; (c) Structural view of sensing $\mathrm{Co}^{+2}$ by A and B.

\section{Conclusions}

The free ligand and the isolated solid metal complexes were fully characterized based on FTIR and UV-Visible spectroscopic results. The two receptors out of four exhibit multiple and similar responses toward $\mathrm{Ni}^{+2}, \mathrm{Fe}^{+3}$, and $\mathrm{Co}^{+2}$ ions. The other competing ions, $\mathrm{Na}^{+}$, $\mathrm{Pb}^{+2}, \mathrm{Mg}^{+2}, \mathrm{Ag}^{+3}, \mathrm{NH}_{4}{ }^{+2}, \mathrm{Mn}^{+2}, \mathrm{Zn}^{+2}, \mathrm{Sn}^{+2}$ were found insensible toward all four . The color changes indicate the metal's coordination with $\mathrm{A}$ and $\mathrm{B}$. A exhibited a clear increase in absorption intensity at $316 \mathrm{~nm}$ and $358 \mathrm{~nm}$ with a significant bathochromic shift of $15-25 \mathrm{~nm}$ while $\mathrm{B}$ in the presence of the same metal ions under similar conditions $\mathrm{Ni}^{+2}, \mathrm{Fe}^{+2}$, and $\mathrm{Co}^{+2}$, ions showed a hyperchromic shift (i.e., $316 \mathrm{~nm}$ to $357 \mathrm{~nm}$ for $\mathrm{Ni}^{+2}, \mathrm{Fe}^{+2}$, and $\mathrm{Co}^{+2}$ ). The disappearance of the $\mathrm{C}=\mathrm{O}$ band and the appearance of the new band at $3339 \mathrm{~cm}^{-1}$ for $-\mathrm{OH}$ reveals the formation of the $\mathrm{A} / \mathrm{Fe}^{+2}$ complex. Chelated carbonyl band at $1623 \mathrm{~cm}^{-1}$ but increase in $\mathrm{N}=\mathrm{N}$ band frequency up to $1461 \mathrm{~cm}^{-1}$ with the appearance of a new band at $3311 \mathrm{~cm}^{-1}$ for $-\mathrm{OH}$ group concludes mechanistic path of formation $\mathrm{A} / \mathrm{Ni}^{+2}$ and $\mathrm{B} / \mathrm{Ni}^{+2}$ cordination. Shifting to lower frequencies for the bands of $v(\mathrm{~N}=\mathrm{N})$ shows the coordination of the $\mathrm{A} / \mathrm{Co}^{+2}$ and $\mathrm{B} / \mathrm{Co}^{+2}$ complex. The present paper reports on the characterization and their electronic absorption spectra of azo dyes and their copper (II), nickel (II), and cobalt (II) complexes which can be useful in understanding the applications of $\mathrm{A}$ and $\mathrm{B}$ diazo compounds as an alternative method for detection of $\mathrm{Ni}^{+2}, \mathrm{Fe}^{+3}$ and $\mathrm{Co}^{+2}$ ions in chemical and clinical applications.

\section{Funding}

This research received no external funding. 


\section{Acknowledgments}

The author is thankful to Arts, Commerce and Science College, Bodwad Dist: Jalgaon Maharashtra (India), for providing laboratory facilities.

\section{Conflicts of Interest}

The authors declare no conflict of interest.

\section{References}

1. Gunnlaugsson, T.; Leonard, J.P.; Murray, N.S. Highly Selective Colorimetric Naked-Eye Cu(II) Detection Using an Azobenzene Chemosensor. Organic Letters 2004, 6, 1557-1560, https://doi.org/10.1021/ol0498951.

2. Lee, S.J.; Jung, J.H.; Seo, J.; Yoon, I.; Park, K.-M.; Lindoy, L.F.; Lee, S.S. A Chromogenic Macrocycle Exhibiting Cation-Selective and Anion-Controlled Color Change: An Approach to Understanding Structure-Color Relationships. Organic Letters 2006, 8, 1641-1643, https://doi.org/10.1021/ol0602405.

3. Gholami, M.D.; Manzhos, S.; Sonar, P.; Ayoko, G.A.; Izake, E.L. Dual chemosensor for the rapid detection of mercury(ii) pollution and biothiols. Analyst 2019, 144, 4908-4916, https://doi.org/10.1039/C9AN01055F.

4. Yang, X., Zhu, F., Li, Y., Yan, M., Cui, Y., \& Sun, G. Yang, X.; Zhu, F.; Yan, M.; Cui, Y.; Sun, G. Three Indole Derived Azo-Azomethine Dyes as Effective Chemosensors for F - Ion and Trace Water Detection. Bulletin of the Chemical Society of Japan 2020, 93, 870-879, https://doi.org/10.1246/bcsj.20200003.

5. Makedonski, P.; Brandes, M.; Grahn, W.; Kowalsky, W.; Wichern, J.; Wiese, S.; Johannes, H.-H. Synthesis of new kinds of reactive azo dyes and their application for fibre-optical $\mathrm{pH}$-measurements. Dyes and Pigments 2004, 61, 109-119, https://doi.org/10.1016/j.dyepig.2003.10.005.

6. Al-Jibouri, M.N. Synthesis and characterization of transition metal complexes with azo ligand derived from 4-hydroxy-6-methyl-2-pyranone. European Chemical Bulletin 2014, 3, 447-451.

7. Akram, D.; Elhaty, I.A.; AlNeyadi, S.S. Synthesis and Antibacterial Activity of Rhodanine-Based Azo Dyes and Their Use as Spectrophotometric Chemosensor for Fe3+ Ions. Chemosensors 2020, 8, https://doi.org/10.3390/chemosensors8010016.

8. Hosseinjani-Pirdehi, H.; Mahmoodi, N.O.; Pasandideh Nadamani, M.; Taheri, A. Novel synthesized azobenzylidene-thiourea as dual naked-eye chemosensor for selective detection of $\mathrm{Hg} 2+$ and $\mathrm{CN}^{-}$ions. Journal of Photochemistry and Photobiology A: Chemistry 2020, 391, https://doi.org/10.1016/j.jphotochem.2020.112365.

9. Dhaka, G.; Jindal, G.; Kaur, R.; Rana, S.; Gupta, A.; Kaur, N. Multianalyte azo dye as an on-site assay kit for colorimetric detection of $\mathrm{Hg} 2+$ ions and electrochemical sensing of $\mathrm{Zn} 2+$ ions. Spectrochimica Acta Part A: Molecular and Biomolecular Spectroscopy 2020, 229, https://doi.org/10.1016/j.saa.2019.117869.

10. Khanmohammadi, H.; Darvishpour, M. New azo ligands containing azomethine groups in the pyridazinebased chain: Synthesis and characterization. Dyes and Pigments 2009, 81, 167-173, https://doi.org/10.1016/j.dyepig.2008.07.019.

11. Mohammadi, A.; Khoshsoroor, S.; Khalili, B. Rapid, sensitive and selective detection of arginine using a simple azo-based colorimetric and fluorescent chemosensor. Journal of Photochemistry and Photobiology A: Chemistry 2019, 384, https://doi.org/10.1016/j.jphotochem.2019.112035.

12. Goswami, S.; Chakraborty, S.; Adak, M.K.; Halder, S.; Quah, C.K.; Fun, H.-K.; Pakhira, B.; Sarkar, S. A highly selective ratiometric chemosensor for $\mathrm{Ni2}+$ in a quinoxaline matrix. New Journal of Chemistry 2014, 38, 6230-6235, https://doi.org/10.1039/C4NJ01498G.

13. Sağırlı, A.; Bozkurt, E. Rhodamine-Based Arylpropenone Azo Dyes as Dual Chemosensor for $\mathrm{Cu} 2+/ \mathrm{Fe} 3+$ Detection. Journal of Photochemistry and Photobiology A: Chemistry 2020, 403, https://doi.org/10.1016/j.jphotochem.2020.112836.

14. Al-Jibouri, M.N. Synthesis and characterization of transition metal complexes with azo ligand derived from 4-hydroxy-6-methyl-2-pyranone. Eur. Chem. Bull 2014, 3, 447-451.

15. Silverstein, R.M.; Bassler, G.C. Spectrometric identification of organic compounds. Journal of Chemical Education 1962, 39, https://doi.org/10.1021/ed039p546.

16. Patel, P.S. Studies on synthesis and dyeing performance of disperse azo dyes based on Schiff base of ninhydrin and 3-amino phenol. Arch. Appl. Sci. Res 2012, 4, 846-51.

17. Mohammadi, A.; Ghasemi, Z. A simple pyrimidine based colorimetric and fluorescent chemosensor for sequential detection of copper (II) and cyanide ions and its application in real samples. Spectrochimica Acta Part A: Molecular and Biomolecular Spectroscopy 2020, 228, https://doi.org/10.1016/j.saa.2019.117730.

18. Khanmohammadi, H.; Rezaeian, K.; Amini, M.M.; Ng, S.W. Azo-azomethine dyes with N, O, S donor set of atoms and their $\mathrm{Ni}(\mathrm{II})$ complexes: Synthesis, characterization and spectral properties. Dyes and Pigments 2013, 98, 557-564, https://doi.org/10.1016/j.dyepig.2013.03.023. 